\title{
COFFEE AND IDENTITY: Consume Coffee, Build Identity, Maintain Variety on Palintang Community West Java
}

\author{
Rahman Latif Alfian, ${ }^{1}$ Budiawati Supangkat Iskandar, ${ }^{2}$ dan Johan Iskandar ${ }^{3}$ \\ ${ }^{1}$ Freelance Researcher, Alumnus of Postgraduate of Anthropology, Faculty of Social and Political Science, \\ Padjadjaran University. \\ ${ }^{2}$ Department of Anthropology, Faculty of Social and Political Science, Padjadjaran University. , \\ ${ }^{3}$ Department of Biology, Faculty of Mathematics and Natural Sciences and Postgraduate of Environmental Study \\ (PSMIL \& DIL) and Institute of Ecology (PPSDAL), Padjadjaran University. \\ E-mail: rahmanlatif927@gmail.com
}

\begin{abstract}
This article discusses the Palintang coffee and its social, cultural and ecological impacts on the people of the Palintang Hamlet. Palintang hamlet is located in directly adjacent to the forest under the management of the State Forestry Corporation (Perhutani). Last fifteen years, the government began to intensify the cultivation of coffee plant in the Palintang hamlet. Palintang hamlet is located approximately 1,400 above sea level. As a result, coffee of Arabica plant (Coffeea arabica L) grows well in the area. The purpose of this article is to elucidate at the impact of coffee on the social identity of the Palintang community. The method used in this study was ethnographic approach which aims to reveal meaning from the point of view which of cultural stakeholders. Some field research techniques, namely observation, deep interviews, and participant observation were applied in this study. The results of this study showed that the coffee cultivation in Palintang hamlet has been an important impact not only an economic, but also social and ecological aspects of the Palintang community. The community always highlight the distinctive characteristics of the Palintang coffee, even some people claim that Palintang coffee has a characteristic that no other coffee has. This process then makes coffee as one of the markers for the community of Palintang, because through coffee of the community members are known to other community groups. The distinctive characteristic of Palintang coffee also adds to the repertoire of varieties of archipelago coffee, especially those related to the character of coffee.
\end{abstract}

Key words: Identity construction; diversity; coffee; local knowledge; Palintang community

\section{KOPI DAN IDENTITAS: Mengonsumsi Kopi, Membangun Identitas, Menjaga Ragam Pada Masyarakat Palintang, Jawa Barat}

\begin{abstract}
ABSTRAK. Artikel ini membahas mengenai kopi Palintang beserta dampak sosial, budaya, serta ekologisnya bagi masyarakat Kampung Palintang, Desa Cipanjalu, Kecamatan Cilengkrang. Kampung Palintang berbatasan langsung dengan hutan yang sekarang di bawah pengelolaan Perum Perhutani. Lima belas tahun ke belakang, pemerintah mulai menggiatkan penanaman kopi di kampung Palintang. Kampung Palintang berada di ketinggian \pm 1400 mdpl, membuat tanaman kopi jenis arabika tumbuh dengan baik di daerah tersebut. Tujuan dari penelitian ini adalah untuk melihat pengaruh kopi terhadap identitas sosial warga Palintang dan bagaimana dampak bagi masyarakat. Penelitian ini menggunakan metode etnografi, penggunaan metode tersebut bertujuan untuk mengungkap makna dari sudut pemangku kebudayaan. Hasil dari penelitian ini menunjukkan bahwa penanaman kopi di Kampung Palintang tidak hanya memberikan dampak secara ekonomi, tetapi juga memberi pengaruh pada aspek sosial dan ekologis bagi warga Palintang. Pada awalnya kopi hanya diproyeksikan sebagai komoditas yang meningkatkan perekonomia warga, meskipun demikian dalam perjalanannya terutama dalam pemasaran, warga secara sadar maupun tidak membentuk citra kopi Palintang. Warga selalu menonjolkan ciri khas kopi Palintang, bahkan beberapa warga mendaku bahwa kopi Palintang memiliki ciri khas yang tidak dimiliki kopi lain. Proses ini kemudian menjadikan kopi sebagai salah satu penanda bagi warga Palintang, karena melalui kopi warga masyarakat dikenal kelompok masyarakat lain. Ciri khas kopi Palintang yang ditonjolkan juga menambah khasanah ragam kopi nusantara terutama yang berkaitan dengan karakter kopi.
\end{abstract}

Kata kunci: Konstruksi Identitas; Keanekaragaman; Kopi; Pengetahuan Lokal; Palintang.

\section{INTRODUCTION}

Coffee, a commodity that has a great influence on human life since it was first discovered (cf. Cotton, 1996) . In fact, it was mentioned that in the course of human civilization only produced three important nonalcoholic drinks, namely tea leaf extract, cocoa bean extract, and coffee bean extract (Ukers, 2012). Coffee itself is the second most valuable commodity in the world after petroleum (Tucker, 2011). Growing coffee plants is increasing every year and tends to be increased, according to Tucker (2011), which is inseparable from the ever-increasing coffee consumption marked by consumer culture, increased appreciation for high-quality coffee, and people's willingness to visit cafes or coffee shops to relax , doing assignments, socializing, or just tasting coffee. In Indonesia itself, coffee consumption habits and the meaning of coffee shops are shifting. The meaning of the coffee shop is shifting where coffee shops are not only a place to enjoy coffee but also a means of meeting, a place to work, as well as a means to get social status, and entertainment facilities (Anrical, 2018).

The question that then arises is why coffee has survived and is so widely popular, not only where it has 
grown, but also in a distant place? The first answer is caffeine which is the content of coffee beans. Caffeine itself has a significant function as a stimulant for the body and has an instant effect in providing the energy, awareness and adrenaline needed by humans. According to Parker and Austin (2011) caffeine is the most commonly used drug in the world because it causes a direct reaction to the body, and most of it is taken in the form of coffee. The second reason coffee is an important part of human life is the socio-cultural and economic factors that surround it. Its great influence on the human body in carrying out daily activities makes coffee plants from planting to becoming a drink cannot be released with the local knowledge of the people who cultivate it. Different environments with different understandings make every society have their own knowledge in cultivating coffee plants to become a drink. Tucker (2011) argues that coffee is a material substance, but growing coffee, drinking coffee, is a culture in which symbolic and social meanings are contained. Similarly, Parker and Austin (2011) also argued where they stressed that there is a great culture in every practice related to coffee because when talking about coffee it cannot be separated from other integrated practices such as association of conversation and brotherhood, political chatter, and others so.

Discussing culture, culture itself can be defined as everything that humans think, have, and do as members of society (Ferraro, 2010). Through culture, consuming coffee can confirm the identity of a group of people, affirm values, and affirm social ties (Tucker, 2011). Tucker further explained that the culture surrounding coffee (coffee culture) can unite actions, beliefs, and special knowledge to distinguish members (groups) from nonmembers. Coffee is a marker for the community holds it because in the cultural era, as we can now and very likely to see a world characterized by certain signs, a sign that can form the identity of groups or sub-groups that make them different from others (Kahn, 2016 ).

Understanding the identity and role that drives people to behave in a protective manner not only has "provocative" implications for research, but also has important practical implications (Clayton and Opotow, 2003). In addition, the discussion on identity also needs to get more attention from academics because identity is needed to drive people's lives today which is marked by modernization, globalization, and nationalism (Retnowati, 2009). At the local level, Clayton and Opotow (2003) revealed that behavior related to the environment such as the environment, protection of nature, requires strong community identity related to identity at the private level, and collected a number of values that will be used controversially. no. Identity itself is always a dialectic between agreed and different (Jenkins, 2008). In this regard,
Stuart Hall (1990) explains that there are two ways to look at cultural identity, namely first through classification such as historical similarities, cultural similarities, and others. And the second through differences such as the significance that distinguishes one group from another. Referring to previous opinions, each community has a special significance seen in the wider community group to identify the identity of the community.

Some research on coffee that has been done previously discusses the history of coffee in the archipelago. For example, research on Coffee Production in Priangan in the 19th Century (Muhsin, 2017) which explained some of the characteristics of coffee in Priangan, the selling price of coffee in Priangan in the 19th century, and its impact on coffee farmers at that time. Research from Lasmiyati (2015) also discusses about Coffee in the Priangan XVIIIXIX Century, the study tells the journey of coffee planting and various policies made by the colonial government in growing coffee in West Java. In another social aspect, coffee research in West Java in particular also discusses the economic benefits gained by coffee farmers. For example, research on the Analysis of Java Preanger Coffee Farmer Business Income in the Margamulya Farmer Group Margamulya Village, Pengalengan District, Bandung (Audry and Djuwendah, 2018). Research from Widiyanto (2017) on the Activities and Time Out of Farmers in the Social Forestry Program in Ciamis, West Java also explains the advantages and advantages of coffee farmers when compared to cardamom farmers and papaya farmers.

Regarding the previous research, this paper is to elucidate the impact of coffee on the social identity of the Palintang community which is based on case study in Palintang Hamlet of Cipanjalu Village, Bandung West Java.

\section{METHOD}

Method used in this study was qualitative. This study focuses on the practice of a community member behavior which ethnographically would be displayed in the discourse of coffee construction into a social identity for the people of Palintang. Ethnography was used in this research which is based on the core of ethnography is an effort to pay attention to the meaning of the actions of events that are observed in the community groups (Spradley, 2007). The Palintang is presented as a locus where the process of identity construction is carried out by community of Palintang. Of course in its formation the Palintang identity does not become a monolithic locus, there is interaction with the locus outside the Palintang area. Palintang hamlet became the location of the study because since fourteen years ago, community members, initiated by Perhutani, began growing coffee in the forests 
around Palintang hamlet. Coffee planting since then and continued to be added to the subsequent planting, more or less had an impact on the community. The first impact seen is economic impact, while the other impact is social influence. Gradually for fourteen years, coffee became a part of the life of the Palintang community. Coffee also has its own meaning in daily life. The Palintang community began to work in the coffee plantation sector, from gardens to post-harvest work. Previously, almost $90 \%$ of the people of Palintang worked as vegetable growers. At present the percentage starts to decrease as they move into coffee farmers. The community also began to process coffee up to the ready to use stage and some began to build simple coffee shops. These developments and changes have made Palintang Village interesting to study more deeply.

In this study the reading of the concept of culture is understood as being flexible, negotiable, fought for, relative, and subject to change (King and Wilder, 2012: 318). Culture that was formed was then seen as a differential culture that grew out of the continuous interaction between people, groups and the environment that constantly changes (Abdullah, 2015: 5). Furthermore, identity is understood as a cultural concept described earlier. Identity itself is formed by social processes, once acquired its form, identity is then maintained, modified, or even reshaped by social relations (Berger and Luckmann, 2013: 235). In other words, identity is not a fact that has been achieved, but is a "production" that is never finished, always in the process and always in representation (Hall in Rutherford, 1990: 222).

Through a description of the concept of culture and identity in the previous paragraph, some techniques, including observation, participation and participant observation, and deep interview were applied in this study. Regarding observation, researchers observed the environmental conditions of Palintang ecosystems, including the settlement, coffee garden, and forest. In addition, the researchers observed various activities of informants, including management of coffee farming consists of seed selection, land preparation, maintaining coffee tree, harvesting, coffee processing after harvesting, and marketing of coffee beans. The participant observations were undertaken by both observations and involving of the researchers with some activities of the management of the coffee farming system of Palintang (cf. Bernard, 1994).

Data collection was also carried out by depth interviews with informants. The deep interview was chosen because to collect historical data on Palintang coffee over times from last time to the present time, which in the past few years have been echoed as a marker of both the socio-economic and cultural aspects of community and biophysical aspects of Palintang community. The deep interviews were aimed for informants who consider they knew in depth the data needed in this study. In this study, deep interviews were undertaken to several informal leaders (sesepuh), heads of coffee farmer groups (ketua kelompok petani kopi), male and female coffee farmers, coffee traders in Palintang, and village officials (perangkat desa). This interview aimed to complete and check research data obtained during the deep interviews. The interview model was often used by researchers when they were in a coffee shop, when they met with Palintang people who also enjoy coffee. This interview was also often used by researchers when observing coffee gardens, and when observing residence of the Palintang Village.

Analysis data involved cross-checking, summarizing and synthesizing from different sources, including observation, participant observation, and deep interview to build up a narrative account (cf. Newing et al. 2011; Iskandar 2018). Moreover, it made the narrative with focused on descriptive and analytical. Thus, the data analysis consists of four stages, namely data collection, data reduction, data presentation, and conclusion or verification. The process was carried out repeatedly to get a certain pattern in the community studied. In conducting data analysis the flow was not always sequential because these steps are something intertwined at the time before, during, and after collecting data in a parallel form, to build general insights called analysis. Whereas in the data verification process, researchers used triangulation. Where the researcher compared the observational data with the data obtained at the interview. The researcher also compared interview data from one informant to the other informants.

\section{Study site}

This research was conducted in Palintang hamlet, Cipanjalu village, Cilengkrang sub-district, Bandung district, West Java (Figure 1).

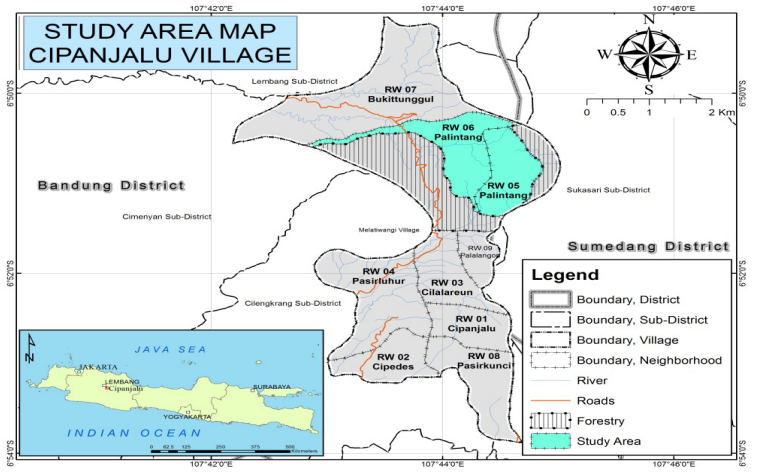

Figure 1. Study area of Palintang hamlet, Cipanjalu village, Cilengkrang sub-district, Bandung district, West Java

Source: Iskandar et al (2017)

Geographically Palintang is located approximately latitude 107043'30'-107044'00" North and longitude 
6045'15"-6051'30" East. Palintang hamlet is situated about $8 \mathrm{~km}$ to the north of Ujung Berung, and is positioned approximately between 800 and 1,400 m above sea level. This hamlet is surrounded by pine forest (Pinus merkusii) and quinine (Cinchona calisaya) plantation. Administratively, Palintang hamlet to the north and to east is bordered to the forest of State Forestry Corporation (Perhutani), to the south is bordered by Ciporeat village, and to west is bordered by Bukit Unggul hamlet (Gunung Kasur).

In 2018 the estimated population of Palintang was 632 households. The majority of people of Palintang hamlet have main livelihood as farmer and labor farmer. Main agroecosystem types of Palintang are recorded the homegarden, garden, vegetable garden and farming coffee (Coffea arabica L) trees that is mixed with pine trees of the Perhutani forest by applying of tumpang sari system (Iskandar et al 2017). Banana trees have been commonly planted in the homegarden, garden, and more recently both banana and coffee trees have been introduced in the Perhutani forest to minimize the vegetable garden in the forest, to avoid soil erosion, to improve soil fertility, and to provide good income for the local people of Palintang hamlet. Banana trees (Musa paradisiaca) have been predominantly interplanted with other annual as well as perennial trees, including coffee, alvocado (Persea americana), mango (Mangifera indica), pine, and suren (Toona sureni).

\section{RESULTS AND DISCUSSION}

\section{Palintang people and faming coffee}

Cultivation of coffee in Java, especially for world marketing purposes, had been started since the early 18th century by Dutch Colonial (Breman, 2014). One of the coffee planting areas formed by the Dutch colonial government was Priangan (West Java at the present time) (Geertz 1963; Lasmiati, 2015; Putra and Ferry, 2015; Farokhah, 2017; Zakaria, 2017). This ecological history was explained at least by one informant of the elders (sesepuh) in the Palintang. Palintang residents believe that coffee in their area has existed since the Dutch colonial times. Nevertheless, planting coffee was not the main livelihood of residents in the Palintang since that time. One of informants explained that coffee in Palintang had already been exist there but the majority of residents were mostly brought by the Dutch colonial government to plant quinine and only a few people were ordered to grow coffee. After the Dutch colonial times, however, residents themselves have mostly chosen as vegetable farmers.

Ecologically, Palintang is situated in mountainous area, located in the high land approximately 1,400 $\mathrm{m}$ above and average annual rainfall is $2,120 \mathrm{~m}$ (https://en.climate-
data.org/asia/Indonesia/central.Java/bandung-607890/. Since the Palintang is located in the high land, this area suitable for farming Arabica coffee (Coffea rabica L). As many documented that Arabica coffee well in region between 1,000 and 2,000 above sea level and high rainfall (Kurniawan, nd; Hulupi and Martini, 2013; Nugroho et al. 2016; Iskandar et al. 2018).

The reason the ecological appropriate of Palintang for planting coffee was to raise idea of Perhutani to introduce coffee in this area. Before the 2000s the majority of Palintang residents had not planted coffee. This was because the price of the coffee market at that time according to informants was less promising, so that residents were not interested in planting it. Even so, some residents have started growing coffee since the late 1990s, some residents realized that Palintang was suitable for coffee cultivation. In addition, residents who planted coffee since then know the story of the past coffee planting carried out by the predecessors of Palintang residents. These residents became actors who are now as respected old men (disepuhkan) and considered as senior and expert in the cultivation of coffee in the Palintang.

Some reasons for the actors are interested in farming coffee, such as they have past knowledge of coffee planting in Palintang and also the awareness that forest land of Perhutani in Palintang is increasingly being eroded into forested land that can be restored by intercropping with coffee plant. Empirically, it has been found in Palintang, forest land around the Palintang village at that time was used by residents as vegetable farming. Although forest wood trees, such as pine, has been still planted (because there are indeed regulation for planting pine trees), the land that has been used to plant vegetables is increasingly showing its ecological negative effects. Several of the informants told us that growing vegetables in Palintang made land more "damaged", some locations occurring soil erosion and landslides even though the impact was not too large. In addition, massive vegetable planting makes the soil's capacity to absorb water less. Soil is not able to penetrate water into the deep soil because of the decreasing number of trees in the forest. Among these environmental reasons were one of the reasons that several actors in Palintang began to intensify coffee cultivation under the direction of Perhutani.

Coffee cultivation in the Perhutani pine forest in Palintang began to be actively socialized in 2004 . The government represented by Perhutani provided a socialization program for the Community Based Forest Management (CBFM or PHBM=Pengelolaan Hutan Berbasis Masyarakat) in which the program invited the community to jointly manage the forest. The follow-up of this program is the planting of perennial plants in the Perhutani forest area. Perhutani provides knowledge 
about the planting program of perennial plants, such as coffee (Coffee arabica), avocado (Persea americana) and jackfruit (Artocarpus hetrophyllus) to replace vegetable planting that has been carried out by the Palintang community. One of the residents who became a coffee planting actor in Palintang explained that at that time not only was given knowledge about planting coffee, but also socialized the distribution of yield from coffee and the selling price of coffee. Increasingly promising coffee prices have made residents slowly start farming coffee (Iskandar et al 2018).

In Palintang itself coffee is predominantly harvested once a year from April to July. After the harvest period the coffee plants will flower again, bear fruit, and be harvested again the following year. Palintang residents plant coffee in stages, starting from 500 trees and each harvest has the advantage or capital of farmers by adding coffee trees planted. At present time the Palintang residents have an average of 1,000-2,000 coffee trees on agroforestry system. The planting of coffee by the residents themselves also depends on the area of land they cultivate. In one harvest, 1,000 coffee trees during the productive period will produce approximately 4 tons of coffee beans. Meanwhile, for the price of coffee beans in the form of cherries, in 2019 around Rp. 9,000.00-Rp. 10.000,00. This price will be different when it has undergone processing which includes stripping, washing, and drying. Informants, coffee farmers in Palintang argued, one of the obstacles in planting coffee is the capital that must be spent to start growing coffee. Some coffee farmers say that more capital is needed to grow coffee compared to growing vegetables. However, if the coffee has grown well, the cost is less than the vegetable. This is one reason residents gradually plant coffee in the Perhutani forest. In addition, easy maintenance and long life of coffee plants with long productive periods are also the reason for residents to plant coffee in the Palintang.

\section{Palintang coffee: Livelihoods and Life}

Coffee cultivation in Palintang had been started since the Dutch colonial period as one of the plants that must be planted. It was like being stopped, but the coffee was planted again by residents starting in the 2000s. Coffee cultivation has been increasing because of support from the government through Perhutani's Community Based Forest Management Program $(\mathrm{PHBM}=$ Pengelolaan Hutan Berbasis Masyarakat) (Iskandar et.al. 2018). Perhutani has an important role in planting coffee in Palintang, prohibiting vegetable planting in the forest, to socializing, as well as teaching coffee making Perhutani's role cannot be ignored. Gradually the forests around the Palintang village are overgrown with coffee plants which are increasingly growing in size. In the use of forests by communities under the management of Perhutani, both of them benefit from a profit sharing system. Perhutani as administrator gets $30 \%$ of the harvest, while farmers get $70 \%$ of the harvest.

Coffee farming in Palintang itself has caused changes to the residents of Palintang. Gradually now the changes began to appear in the daily lives of the Palintang people. Previously, most of the Palintang residents worked as vegetable farmers, now their livelihoods are added as coffee farmers. Vegetables have not been completely abandoned by the community, although there are calls for a ban on growing vegetables in the forest (Figure 2a and Figure 2 b). Of course to leave vegetable farming completely requires a long time, residents reasoned that planting vegetables has been done since its predecessor so that the activity is difficult to abandon the residents of Palintang now.

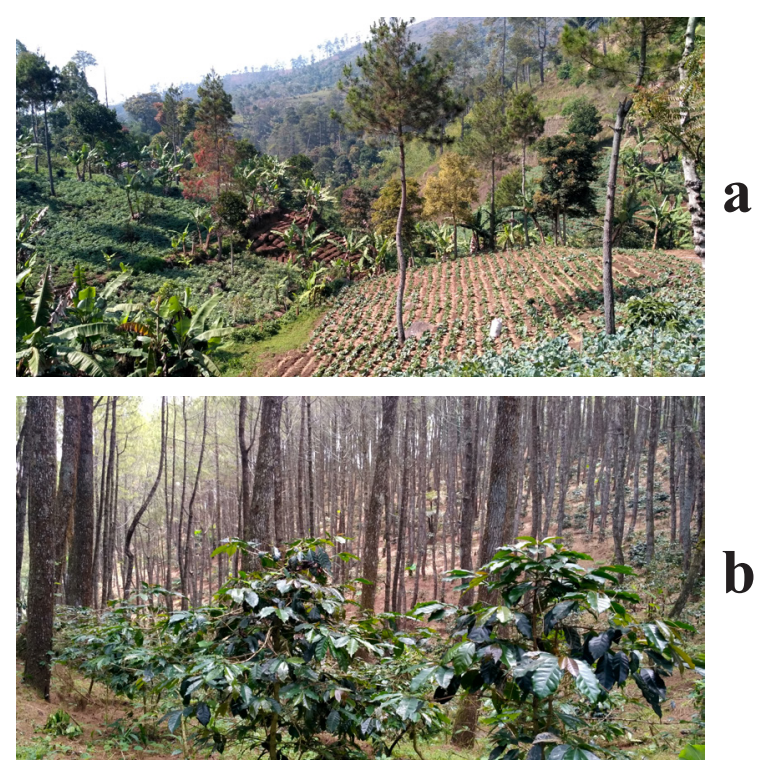

Figure 2. a. Pine forest plot is being planted by vegetables, and $b$ Pine forest is grown by Arabica coffee trees

Many people of Palintang have interested in involving in planting coffee trees in the Perhutani forest because economic benefits. It cannot be denied that something new will be accepted if it is considered able to provide economic benefits and not make drastic changes for a community (Aryadi, 2012: 144). One of the informants, resident of Palintang planted coffee as mentioned earlier because the price of coffee tends to be higher and more stable than the price of vegetables. Initially coffee was not taken into account because the selling prices were cheap and there were no real examples of Palintang residents who were successful in managing farming coffee garden. Coffee cultivation itself requires a struggle that is not easy because the new coffee trees can be harvested after 3-4 years after planting. During the initial planting in Palintang, residents still planted vegetables in the forest area as an effort to meet their economic needs. Vegetable plants are planted around new coffee plants planted in 
the forest area. Vegetable crops planted include potatoes, cabbage and tomatoes. Vegetable planting stops when the coffee trees have grown, this is because the coffee trees cover the sun to the ground which makes vegetable crops cannot properly grow.

In addition, some struggles have involved by Palintang coffee farmers in finding networks to sell coffee. One of the informants, a senior coffee farmer of Palintang, pseudonym called as Pak Aep Palintang (58 years), mentioned that in the early coffee planting period in Palintang, confused where to sell his coffee production. Pak Aep was later on assisted by Perhutani to sell the harvested coffee. From this coffee sales process, Pak Aep began to build relationships with other regional coffee middlemen (bandar or pengepul), such as Sumatra. Gradually the management of coffee by Pak Aep is growing. He began to grow coffee in a small amount of forest but now has thousands of coffee trees. Initially the seeds planted were seeds that grew wild in the forest, and now he is made of a nursery these coffee seedlings to be planted by other residents. The success of this coffee management makes people interested in planting coffee. Pak. Aep is now recognized as one of the coffee middlemen (pengepul) Palintang hamlet, besides that, he is also the chairman of one of the coffee farmers' association in Palintang.

In Palintang, coffee farmers are members of farmer associations where each group consists of 10-20 members (coffee farmers). Each group of coffee farmers association has a leader who usually becomes a middleman or collector of coffee beans that have been harvested. The sale of coffee beans from farmers to the urban in the form of wet coffee beans or residents call them as 'cherry'. Moreover, after the coffee beans have been held by pengepul, the beans have been proceeded (washing, stripping and drying), most of the middlemen (pengepul) in Palintang sell coffee beans to a larger middlemen in the city in the form of "gabah" (the form of seeds that have been peeled and dried). The price of coffee beans in the form of "gabah" ranges from Rp. 26,000.00 - Rp. 30,000.00. This price will be more expensive if other processing is carried out, such as called as "natural" processing (coffee beans are dried without washing and peeling) or called as "honey" processing (coffee beans are dried in the sun after being peeled without washing). But for these two processing are rarely demanded in large quantities.

Because the management of coffee has been improving, the coffee commodity more develop to be a main commodity in Palintang hamlet. The sale of coffee beans from Palintang has increasingly increased not only in the local market (in West Java) but also in the national market. One of the coffee collectors in Palintang (Pak Jajang, 46 years) explained that the demand for coffee on the market has been increasing every year. For example two years ago, each time he sold coffee in the form of grain (gabah) to collectors larger than 5 tons to 10 tons, whereas last year he received requests from collectors as much as double the amount previously deposited. Increased coffee appreciation among coffee connoisseurs or coffee lover (pencinta kopi) and the community at large makes each coffee-producing region trying to show the distinctive characteristic of coffee beans from the region. The government of West Java Province itself encourages coffee production as an effort to introduce West Java specialty coffee to the wider community, besides that step is also an effort to improve West Java's economy (quoted from repubika.com, 2016). Similarly, in Palintang, coffee collectors and farmer group leaders are well aware that Palintang coffee must be promoted to other regions widely to have more bargaining value. Several leaders of farmer association began to learn how to process coffee to become beans that had been 'roasted' and coffee granulated. One of farmer associations has been assisted by a group of campus community tries to process coffee to granulated and sell it in packaged form. The chairman of the farmer association said that selling ready-made coffee (coffee granulated) and brewed coffee was their attempt to introduce the distinctiveness of Palintang coffee to the wider community (Figure 3).

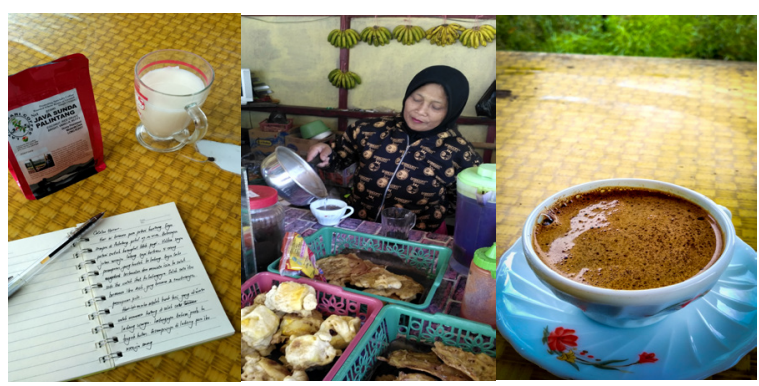

Figure 3. Coffee product processed and sachet coffee are being traded by a women in small shop (warung) of Palintang hamlet

The development of the processing of coffee products by the people makes coffee in Palintang, which is run by the community of coffee lovers. Coffee is treated by the public like daily drinks. In contrast to the Sundanese community, generally in other areas that are used to consuming fresh tea, most Palintang residents, especially men, have a habit of drinking coffee (ngaleueut kopi or minum kopi) in the morning and/or in the afternoon (cf. Igarashi, 1985). Similarly when presenting guests from outside the area, the persons who received guests presented coffee drinks and always mentioned that "this is typical Palintang coffee". In addition, Palintang coffee farmers often tell the history of the Palintang coffee, the character of the coffee plant, and distinctive taste character of the Palintang coffee.

Occasionally some coffee farmers from Palintang also participated in coffee exhibitions organized by 
the government of West Java and the Palintang coffee competition that is the character of the taste of the Palintang coffee beans. From the exhibitions and competitions that were followed, Palintang coffee farmers knew that the character of the Palintang coffee flavor tended to be "fruity" which was fresh bitter acid and had a fruit aroma such as jackfruit and banana. This special taste of coffee according to coffee farmers in Palintang is influenced by coffee plantations which are also planted with other plants such as jackfruit, banana and avocado in the agroforestry of Perhutani forest.

The activity took part in the exhibition and the competition was held to introduce and get recognition from the groups themselves and groups from outside the Palintang hamlet. The actions taken by the resident of Palintang as described by Barth (1988), that identity basically has a relational nature, in which identity is created, maintained, and transformed through interaction and the relationship between them is defined as "we" (their own group) with people others are defined as "they" (other groups). The introduction of the characteristics of coffee plants and the taste of coffee according to one resident is to introduce to the general public that coffee Palintang has a different character than coffee from other regions.

Accordingly, along with changes in times, coffee have been inspiring and a media for the Palintang community in protecting the Perhutani forest by managing the coffee agroforestry. Indeed since coffee have been providing good income for the community of Palintang. Coffee has been symbol of prosperity that means economic prosperity. The process of identifying coffee symbols has been undertaken by gradual process of means, including coffee drinking habits, success stories, experiences, labeling, coffee as an important commodity as an economic plant has economic value and identity (cf. Yenrizal et al. 2018). The story built from coffee such as the history of coffee cultivation in Palintang has been an important role in maintaining a local variety of coffee when compared to other coffee varieties in West Java in general. It has mentioned by many scholars, such as Brush (1992) and Prober et al. (2011) that socio-economic and cultural aspects has generated collection actions to conserve varieties of crops across culture in the world.

\section{CONCLUSION}

Based on ecological history, in contrast to the general Sundanese community, which has a basic livelihood of cultivating rice in the fields, the Palintang community is not involved in rice cultivation in the we-rice field (sawah), because there is no "sawah" area in the area. Since considering the Palintang community has intensive interactions over time with the environment, in the form of the Perhutani forest area, in the form of highland mountainous areas, with cold temperatures, and fertile soil, Palintang community have involved in vegetable cultivation. They plant vegetables in "tumpang sari" on the Perhutani forest. Tumpang sari may be defined as reforestation under which farmers are permitted to agricultural crops between the rows of the forest plant species; their payment for restoring the plot is the usufruct right to that land intercropped species. Palintang residents have deep local knowledge in cultivating annual crops, including vegetables, because in the past they have been involved in "tumpang sari" programs on land since the Dutch colonial government, the Forestry Service (Dinas Kehutanan) or Perhutani post-independence.

Cultivation of vegetable in the forest area of Perhutani even though it has high economic benefits, but has some negative impacts on the environment, such as the emergence of agricultural erosion, and pollution of pesticide poisons, Consequently, in the early 2000s, the government through Perhutani promoted coffee cultivation, with agroforestry system in Perhutani forest. The aim is to improve the forest environment and provide economic benefits for the people of Palintang. Given that the Palintang region is suitable for planting Arabica coffee (Cofea arabica), and can provide economic benefits to the Palintang community.

Therefore, the effort to develop coffee cultivation undertaken by Palintang residents, especially coffee farmers, made the socio-economic conditions of the Palintang community change. Coffee which was initially underestimated is now one of the sources of livelihood for the community of Palintang. The increasing coffee cultivation and coffee farmers in Palintang make coffee increasingly imbued as the self-reliance of the people of Palintang. With the coffee being consumed, coffee is a marker for Palintang residents. In addition, as a commodity used for "fence" in forest conservation and types of coffee. In other words, coffee can be a commodity producing money and a family source of income, and can be a distinctive identity in the Palintang community, through social processes in society, such as drinking habits, stories of success, experience, labeling, and yields. Indeed, by adoption of the Palintang community in the forestry forest in Perhutani, the important impact not only economic, but the social and ecological aspects of the Palintang community.

\section{ACKNOWLEDGMENT}

This research was funded by the Academic Leadership Grant (ALG) Program of Prof. Johan Iskandar. So, we are grateful to the Rector of Padjadjaran University for funding and supporting this research. We are also grateful to the formal village leaders, the formal hamlet leaders, 
and the informants for allowing research, and assisting and providing various information during our research in Palintang.

\section{REFERENCES}

Abdullah, I. (2015). Construction and Reproduction of Culture. Yogyakarta: Pustaka Pelajar.

Anrical. (2018). Coffee Shops and Public Spaces (Study of Shifting the Space for Expression of Free Time to the Space of Popular Cultural Entities) Unpublished Thesis of Universitas Negeri Makassar.

Aryadi, M. (2012). Community Forest: Phenomenology of Community Cultural Adaptation. Malang: UMM Press.

Audrey, R.J. \& Djuwendah, E. (2018). Analisis Pendatan Usaha Tani Kopi Java Preanger Pada Kelompok Tani Margamulya Desa Margamulya, Kecamatan Pengalengan Bandung. Jurnal Ilmu Pertanian dan Peternakan. 6, (1), 31-38.

Barker, C. (2004). The Sage Dictionary of Cultural Studies. Sage Publications.

Barker, C. (2013). Cultural Studies, Theory and Practice. Translated by Nurhadi. Yogyakarta: Kreasi Wacana.

Barth, F. (1988). Ethnic Groups and the Limits of the Social Order of Cultural Differences. Translated by Susilo, N.L and Parsudi Suparlan. Jakarta: UI Press.

Bernard, H.R. (1994). Research Method in Anthropology: Qualitativre and Quantitative Approaches. London: Sage Publications.

Berger, P.L. \& T. Luckmann. (2013). Social Interpretation of Reality: Minutes on the Sociology of Knowledge. $10^{\text {th }}$ print. Translated by Basari, H.. Jakarta: LP3ES.

Brush, S.B. (1992). Ethnoecology, Biodiversity, and Modernization in Andean Potato Agriculture. $J$. Ethnobiol, 12, (2), 161-185.

Clayton, S. \& Opotow, S. (2003). Identity and the Natural Environment The Psychological Significance of Nature. Cambridge: The MIT Press.

Cotton, C.M. (1996). Ethnobotany: Principles and Applications. London: Sage Publications.

Ferraro, G. \& Adreatta, S. (2010). Cultural Anthropology: An Applied Perspective, $8^{\text {th }}$ edition. USA: Wadsworth.

Geertz, C. (1963). Agricultural Involution: The Process of Ecological Change in Indonesia. Berkeley: University of California.
Hall, S. (1990). Cultural Identity and Diaspora. In Rutherford, J (ed), Identity Community, Culture, Difference. London: Lawrence \& Wishart.

Hulupi, R., \& Martini, E. (2013). Guideline for Cultivation and Maintenance of Coffee Plant in Mixed-graden. Bogor: World Agroforestry Center (ICEAF).

Igarashi, T. (1985). Some Notes on Subsistence in A Sundanese Villge. In S.Suzuki,

Soemarwoto, O. \& Igarashi, T. (eds), (1988). Human Ecological Survey in Rural West Java in 1978 to 1982. Tokyo: Nissan Science Foundation, Pp.9-77.

Iskandar, J. (2018). Ethnobiology, Ethnoecology and Sustainbale Development. Yogyakarta: Plantaxia.

Iskandar, B.S, Iskandar, J., Wibawa, H.A. \& Partasasmita, R. (2017). Farmers and tumpang sari: Case study in Palintang Hamlet, Cipanjalu Village, Bandung, Indonesia. Biodiversitas, 18, (3): 1135-1149.

Iskandar, B.S., Iskandar, J. \& Partasasmita, R. (2018). Planting Coffee and Take Care of Forest: A Case Study on Coffee Plantation in the Forest Carried Among People of Palintang, High Land Bandung, West Java, Indonesia. Biodiversitas 19, (6). 21832195.

Jenkins, R. (2008). Rethinking Ethnicity Second Edition. Sage Publications.

Kahn, J.S. (2016). Culture, Multiculture, Postculture: Cultural Diversity and Global Capitalism Imperialism. Yogyakarta: INDeS [Indonesian].

King, V.T. \& William, W.D. 2012. Modern Anthropology in Southeast Asia An Introduction. Translated by Kadir, H.A. Yogyakarta: Kreasi Wacana

Kurniawan, A.S.P. (2017). Coffee catalogue. Jakarta: Yayasan Belantara.

Lasmiati, (2015). Priangans Coffee in XVIII-XIX Century. Patanjala, 7, (2), 217-232

Muhsin, M. (2017). Produksi Kopi di Priangan pada Abad ke-19. Jurnal Paramita: Historical Studies Journal, 27, (2), 182-194.

Newing, H., Eagle, C., Puri, R. \& Watson, C.W. (2011). Conducting Research in Conservation: A Social Science Perspective. London and New York: Routledge.

Nugroho, D.P., Basunanda, P., \& Suryadi, M.W. (2016). Physical Bean Quality Arabica (Coffea arabica) at high and medium altitude. Pelita perkebunan 3, (3) 
Putra, S. \& Ferry, Y. (2015). Performance of Java Preanger Arabica Coffee in West Java. Sisrinov, 3, (3), 113126

Parker, S.F \& Michael, A.W (ed). (2011). Coffee Philosophy for Everyone: Grounds for Debate. United Kingdom: Wiley-Blackwell.

Prober, S.M., O’Connor, M.H. \& Walsh, F.J. (2011). Australian Aboriginal Peoples' Seasonal Knowledge: A Potential Basis for Share Understanding in Environmental Management. Ecology and Society, 16, (2),12

Retnowati. (2009). Kethoprak as Identity (A Study of Arum Budoyo’s Kethoprak Group in Juwana, Pati, Central Java) Disertation. Depok: Universitas Indonesia.

Rutherford, J. (1990). Identity Community, Culture, Difference. London: Lawrence \& Wishart.

Tucker, C.M. 2011. Coffee Culture: Local Experiences, Global Connection. New York: Routledge.
Ukers, W.H. (2012). All About Coffee: A History of Coffee From The Classic Tribute To The World's Most Beloved Beverage. Massachusetts: Adams Media.

Widiyanto, A. (2017). Aktivitas dan Curahan Waktu Petani Dalam Program Perhutanan Sosial Di Ciamis Jawa Barat. Jurnal Hutan Tropis. 5, (1), 48-55.

Yenrizal., Iskandar, J., Rahmat, A. \& Bazari, A. (2018). Ethnoecology Communication of Semende People Interpret Nature. Yogyakarta: Phoenix Publisher.

Zakaria, M.M. (2009). Coffee Priangan in the Nineteenth Century. Historia: International Journal of Historical Education, X (2):131-150.

Republika. (2016). Aher Dorong Peningkatan Produksi Kopi Jabar. https://nasional. republika.co.id/ berita/nasional/daerah/16/10/18/of8kvh365-aherdorong-peningkatan produksi-kopi-jabar 